\title{
Combined assessment of the environmental, economic and social impacts of structural solutions for residential construction
}

\section{Evaluación combinada de los impactos ambientales, económicos y sociales de soluciones estructurales para la construcción de viviendas}

\author{
E. Fraile-García $^{(*)}$, J. Ferreiro-Cabello ${ }^{(* *)}$, E. Sodupe-Ortega ${ }^{(*)}$, A. Sanz-Garcia ${ }^{(* *)}$
}

\begin{abstract}
Sustainable development in construction is based on three fundamental pillars: economic, environmental and social. This type of approach aims to identify the best possible solutions for sustainably developing structures by conducting a joint evaluation of the impact on those three pillars. The proposed methodology incorporates metadata on the Spanish construction sector. First, a discrete database is generated with 360 alternatives covering a range of common solutions in residential building. A Pareto algorithm is utilized to select the optimal choices and the wide range of solutions is reduced to the $5 \%$ of the initial group. The project manager is therefore provided with an objective assessment of suitable structural alternatives including the overall joint economic, social, and environmental impact. The results obtained demonstrate the importance and utility of the proposed methodology for sustainable construction.
\end{abstract}

Keywords: Sustainable construction; reinforced concrete; one-way slab; social impact; life cycle analysis.

\section{RESUMEN}

El desarrollo sostenible aplicado a la construcción se basa en tres pilares fundamentales: económico, medioambiental y social. El objetivo principal es identificar las mejores soluciones en términos de desarrollo sostenible de alternativas estructurales a partir de la evaluación conjunta de los impactos en dichos pilares. La metodología propuesta incorpora metadatos con información del sector de la construcción en España. Primero se genera una base de datos discreta de 360 alternativas estructurales que cubren el rango de soluciones habituales en edificación residencial. La selección de alternativas óptimas se realiza mediante el algoritmo de Pareto. El abanico de soluciones se reduce al $5 \%$ de las iniciales. Se aporta una valoración objetiva que orienta al proyectista en la selección de alternativas estructurales idóneas, visualizando de forma conjunta el impacto económico, social y ambiental. Los resultados obtenidos muestran la importancia y utilidad de la metodología propuesta en el campo de la construcción sostenible.

Palabras clave: Construcción sostenible; hormigón armado; forjado unidireccional; impacto social; análisis ciclo de vida.

(*) EDMANS Research Group - University of La Rioja (Spain).

(**) Qualiberica SL. - Department of Engineering, Madrid (Spain).

(***) Division of Pharmaceutical Biosciences - University of Helsinki (Finland).

Persona de contacto/Corresponding author: esteban.fraile@unirioja.es (E. Fraile-García).

Cómo citar este artículo/Citation: Fraile-García, E., Ferreiro-Cabello, J., Sodupe-Ortega, E., Sanz-Garcia, A. (2015). Combined assessment of the environmental, economic and social impacts of structural solutions for residential construction. Informes de la Construcción, 67(539): e101, doi: http://dx.doi.org/10.3989/ic.14.041.

Licencia / License: Salvo indicación contraria, todos los contenidos de la edición electrónica de Informes de la Construcción se distribuyen bajo una licencia de uso y distribución Creative Commons Reconocimiento no Comercial 3.o. España (cc-by-nc). 


\section{INTRODUCTION}

Since the beginning of the new millennium, construction has been the economic motor of numerous developed countries. Spain, in particular, presents an interesting case (1) (2). Prior to the economic crisis, the significance of the construction sector regarding the Spanish GDP was about $18 \%$. This percentage is far superior to the European Union (EU) average and means that $20 \%$ of working-age Spaniards were employed in construction. However, at this time economic activity in the construction sector in Spain has sunken to historically low levels. Starting in 2008 and through today, the number of companies registered at the Central Company Directory (Directorio Central de Empresas) of the Spanish National Institute of Statistics (INE, Instituto Nacional de Estadística de España) has declined drastically. On the Mediterranean coast, and in Spain in general, there has been a decrease of approximately $8 \%$ in the ending balances of the National Classification of Economic Activities (CNAE, Clasificación Nacional de Actividades Económicas) and a more than $25 \%$ drop in the total ending balances for the construction sector (2). This situation represents a serious economic problem for Spain. At this point in time, the top priority of the Spanish government is to recover from the current economic crisis. Nevertheless, this crisis may also present an opportunity to change the production system of the construction sector in Spain.

According to experts in the field, the current scenario is an historic moment and an opportunity to raise some pressing questions that were not addressed during the height of the housing bubble; or if they were, they were not tackled rigorously. Regarding to developed and developing countries, an upward trend in sustainable development (3) based on the promotion of the principles of sustainable construction has been gradually gaining momentum during recent years (4) (5) (6) (7). One example is the ambitious climate and energy EU 20-20-20 targets for the year 2020. Broadly speaking, this commitment focuses on cutting $\mathrm{CO}_{2}$ emissions by $20 \%$ by 2020 , as well as improving energy efficiency by $20 \%$ and increasing energy consumed from renewable sources by $20 \%$ (3) (8) (9). These 20-20-20 targets represent an integrated approach to combat climate change, achieve the EU's energy policy goals and strengthen EU competitiveness. Along these lines, the goal of this article is to work on the adaptation of new buildings to the EU's proposals for 2020.

Building modelling ought to allow for a significant amount of information to be incorporated in order to facilitate decisions regarding the selection of materials and construction arrangements. Including reliable, high quality information about the environmental impact is a critical component to comprehensive building modelling. Such information can be obtained through the tools for life cycle analysis (LCA), which should be applied to the entire lifespan of the constructive elements (10). However the aforementioned environmental information must be supplemented by other indicators of sustainable construction: financial data or cycle cost analysis (CCA), and social information or social impact analysis of the life cycle (SIALC) (11) (12) (13). The range of the cost analysis proposed involves the production, transport and integration of all materials required for a structural solution. The analysis of the social impact is also evaluated according to the current official standards and the geographical location of the economic activity generated.
In keeping with the Kloepffer's proposal (14), a current trend focuses on the possibility of transforming the values of LCA + CCA + SIALC into a single value. Kloepffer has already suggested two possibilities, both of which are extremely difficult to implement.

However, the European Committee for Standardization (CEN), with the technical standardisation committee on sustainable construction (CEN/TC-350), is developing new standards to adopt the LCA, in accordance with Kloepffer's approach (15). The objective is to develop a useful tool for sustainable construction that is capable of assessing the sustainability of residential building structures. Such an aim represents a radical shift from previous assessment frameworks utilised in this sector. This CEN rule consists of a general set of indicators and a series of standards. The latter are deemed for calculation procedures and are developed for each of the three sustainability features: environmental, economic and social. There are six basic standards in all, plus two additional rules for products. And finally, an additional technical specification regarding the format for reporting environmental product declarations (EPD) is included.

Regarding the assessment of social impact, a common approach is to create a set of consensual indicators that provide quantitative values. This is actually quite complex given the local nuances in the processes involved (16), and the fact that social needs change continuously over time and from one place to another. Several previous studies agree with these observations. In 2006, Hunkeler proposed assessing the working hours involved in production and then, he applied the novel proposal to a case study of two detergents (17). In another study, Norris reveals the relationship between social conditions and level of income (18).

This article presents research focused on integrating possible social impacts into the overall decision-making process regarding the best structural solution given different alternatives. We propose the use of metadata that provide additional information for the decision-making process, as well as eliminating the use of a large number of indicators. Thus, the quantification of the social impact is conducted by observing the economic activity generated in four distinct levels: local, regional, national and international. Firstly, economic activity is calculated based on geographical location. Then, a validation is performed applying the proposed methodology to the case of residential building structures. The following paragraph summarises this process.

Based on prior research, (19) (20) the parameters that are significant and critical for the assessment of reinforced concrete structures were determined. Thus, an initial database, product of prior research, was generated. This database recorded all those structural alternatives that have been frequently implemented in Spanish residential construction during recent years. The environmental and economic impacts that each solution incurs were established by the LCA and the CCA. The Pareto optimisation algorithm was then applied to find the optimal solutions. In this step, the social impact SIALC was included as another feature in each optimal configuration, i.e. the SIALC was provided after the initial optimisation process as additional information to guide the decision-making process. The result is not a single value but rather, a range of optimal alternatives. Henceforth, the proposed methodology is able to jointly and objectively incorporate the three pillars of sustainable construction. 


\section{METHODOLOGY}

The proposed methodology is described in this section. It assesses the degree of sustainability of a structural solution on the basis on three indicators LCA + CCA + SIALC. In this section, the case study is also explained as well as all the particular components of the building in question. Specifically, the floor plan of the proposed residential building measures $12 \times 18$ metres and is located in Spain.

Firstly, a discrete database of 360 structural solutions is developed. Using different structural parameters, all solutions can be generated. The goal is to have a reliable sample of the standard reinforced concrete structures formed by one-way slabs recently built in Spanish residential construction. To define structural solutions of one-way slabs, the most relevant parameters are as follows:

1. Column layout: This parameter affects both arrangements: the beams, a primary structural element and the oneway slabs, a secondary structural element. Taking into consideration the dimensions of the proposed building, $12 \times 18$ metres, four different column layouts are proposed to incorporate this parameter into the methodology. These four layouts allow for different solutions combining common beam separation distances of 4.5 to $6 \mathrm{~m}$ with one-way slabs from 4 to $6 \mathrm{~m}$. As shown in Figure 1, the four alternatives consider for the study are as follows:

a) Layout of short beams and short slabs using 20 columns and three slab spans to provide a Column Index $(\mathrm{CI})=0.089$.

b) Layout of long beams and short slabs using 16 columns and three slab spans to provide a $\mathrm{CI}=0.071$. c) Layout of short beams and long slabs using 15 columns and two slab spans to provide a $\mathrm{CI}=0.067$.

d) Layout of long beams and long slabs using 12 columns and two slab spans to provide a $\mathrm{CI}=0.053$.

2. Structural element of the floor slab: Three variants are proposed: reinforced concrete joist (RCJ), pre-stressed reinforced concrete joist (PRCJ), and in situ concrete joist (ISCJ). The materials and resources utilised in their manufacturing and assembly also have marked differences. Therefore, each solution has a different resistance value. Those options that do not meet the minimal requirements are discarded by analysing all the solutions generated.

3. Lightening element: This component has no structural function. Its sole purpose is to lighten the weight of the proposed solution. Two possible materials are available: vibrated concrete (VC) and expanded polystyrene (EPS). Both possibilities present different properties in regards to the proposed structure's relevant variables, such as weight, thermal performance, price, activity location, etc.

4. Thickness of the floor slab: When using lightweight floor systems, this is the sum of the thickness of the lightening element and the compressive layer. According to Spain's current standard for concrete (EHE-08 article 59.2.1), and for the widely used slab thickness of $30 \mathrm{~cm}$, the minimum value for the thickness of the compressive layer is $5 \mathrm{~cm}$. A thicker compressive layer is considered not profitable, and in case of using EPS elements, the Spanish regulation does not permit to reduce the value from $5 \mathrm{~cm}$. Given this scenario, we maintain the thickness of the compressive layer constant $(5 \mathrm{~cm})$ and the one of the lightening element will vary from 25 to $35 \mathrm{~cm}(30+/-5 \mathrm{~cm})$.

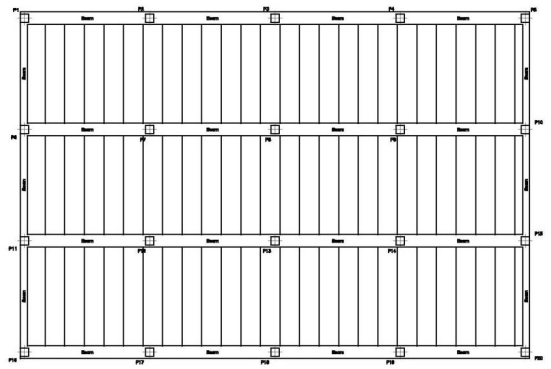

20 Columns (20/Area $=0.089)$

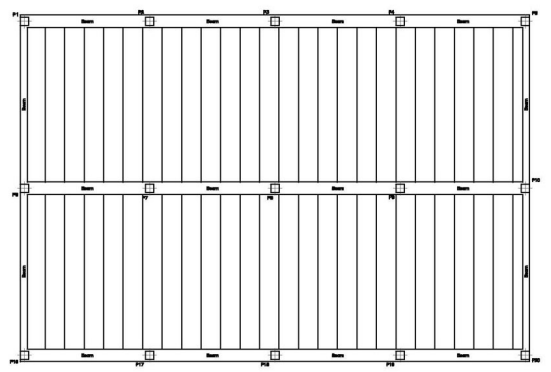

15 Columns (15/Area=0.067)

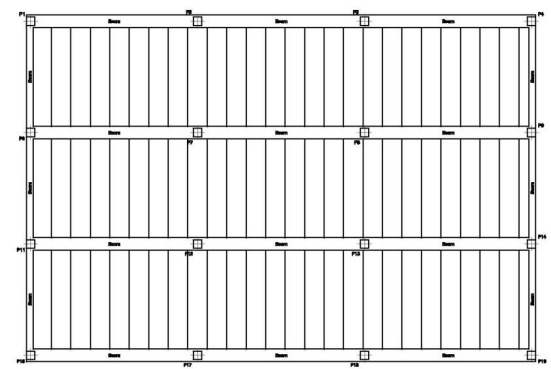

16 Columns (16/Area=0.071)

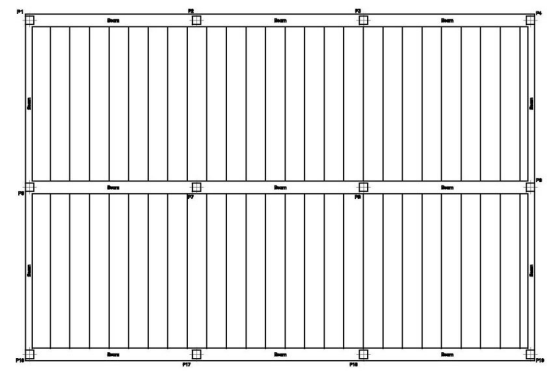

12 Columns (12/Area $=0.053)$

Figure 1. Schematic describing the basic distribution of columns (Column Index, CI) per area of slab used in the validation of the methodology proposed. 
5. Dimensions of flat beams: The use of flat beams in residential construction has been imposed primarily for three reasons. First, modular formwork systems are more profitable; second, operating with these formwork systems offers increased safety, and finally, these beams facilitate managing the diverse constraints of architectural design. A set of solutions is defined using flat beams and varying only beam width, while the thickness of the floor slab remains constant. This value is usually between 30 and $90 \mathrm{~cm}$; consequently, the following values are the discrete values: $30,45,60,75$ and $90 \mathrm{~cm}$. This factor is represented from here on as a percentage of the resistant section (\%RS) for each of the proposed structural solutions (see scheme in Figure 2). This particular structural solution stipulates that all efforts must "circulate" starting at the slab and move toward the primary structural elements, such as beams and columns. The \%RS could also be rightly defined as the ratio of the beam area to the total structure area.

In short, a total of 90 solutions were proposed. These solutions correspond to the combination of three types of structural elements, two types of lightening elements, three values for the thickness of the floor slab, and five different dimensions for the flat beams. The 90 cases for the four column layouts represent the set of possible solutions regularly implemented in one-way concrete slabs for Spanish residential buildings.

Nowadays, the use of different factors to estimate the environmental impact of a structural solution is very common. In 2008, Pacios-Alvarez et al. reported a case study in which two buildings with different structural typologies are evaluated under the current Spanish standard (21). This example case illustrates the determination of the index of structural contribution to sustainability (Índice de Contribución de la Estructura a la Sostenibilidad, ICES). Evaluating the sustainability of the available structural solutions allows companies to incorporate the cost of their emissions as well as the taxes involved to their balances of payments (22).
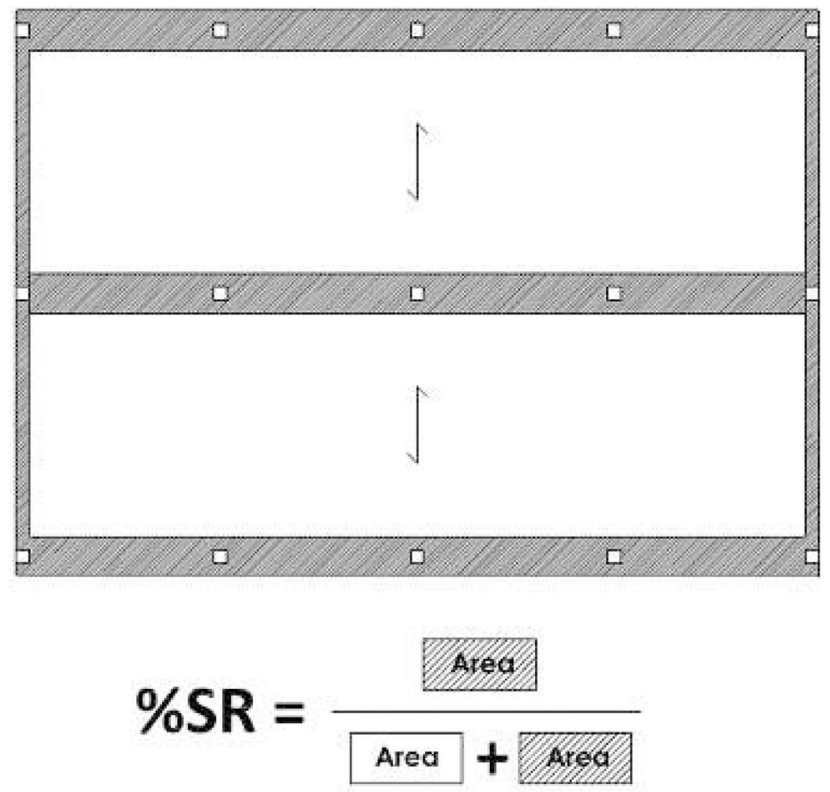

Figure 2. Schematic describing the determination of the percentage of resistant section (\%RS).
The assessment of the sustainability has been carried out in many structural elements. In 2011, Reza et al. analyse the sustainability of unidirectional slabs by including three different materials as lightening elements. In that study they use seven environmental indicators, three economic and also three social indicators (23). In case of columns, two previous works can be highlighted. They proposed different constructive solutions for the columns by varying the geometry, the compressive strength of the concrete and the building process. The first case is a clear application of a multicriteria decision-making process (24). In case of the second one, different algorithms for searching the optimal solution are applied in the same context (25).

This paper focuses on three main elements: beams, columns and floor slabs; however, it also integrates the before-mentioned concept, the three pillars of the sustainable construction. First, several variations of an initial geometry are automatically generated and then, the proposed methodology is applied to perform an integrated modeling of the problem for finding the optimal structural solutions. These solutions can give more support for the final decision-making process.

Subsequently, all the different quantities of the materials used in each structural solution were determined in order to evaluate the various alternatives. These quantities are accurately determined by the structural analyses performed. At this point, those solutions that are not technically feasible are eliminated. Then, both the cost and the environmental impact of the remaining solutions are assessed, while excluding those items that are the same for each solution from the evaluation. Tables 1 and 2 are created to evaluate the cost and environmental impact. These two auxiliary tables reflect the unit cost for all the materials involved in each solution, including their placement, and their potential environmental impact measured in Ecopuntos'99. All the costs employed are listed in a particular database of construction prices (26). The assessment of the environmental impact was then conducted using information gathered after the selection of the most suitable materials in the Ecoinvent database (27). This information was finally complemented with local data.

Table 1. Economic cost of materials.

\begin{tabular}{|l|r|}
\hline Material $M_{i}$ & $\gamma_{i}(€)$ \\
\hline Steel $(\mathrm{kg})$ & 1.21 \\
\hline Concrete $\left(\mathrm{m}^{3}\right)$ & 95.53 \\
\hline Hollow brick H20 (m) & 5.65 \\
\hline Hollow brick H25 (m) & 6.91 \\
\hline Hollow brick H30 (m) & 7.59 \\
\hline Hollow brick P20 (m) & 7.36 \\
\hline Hollow brick P25 (m) & 9.18 \\
\hline Hollow brick P30 (m) & 11.02 \\
\hline Reinforced concrete joist (m) & 2.44 \\
\hline Pre-stressed reinforced concrete joist (m) & 3.51 \\
\hline Column formwork (m²) & 15.38 \\
\hline
\end{tabular}

Source: BEDEC, 2013. 
For this case study, the functional unit is the square meter of the structure built. This takes into account the production of the building materials (columns, beams and floor slabs), their entire operation and transportation and finally their execution. Through a structural analysis, the quantity of material of each proposed alternative is determined as unit of material per square meter. Therefore, CCA and LCA can be obtained using equations 1 and 2, respectively.

$$
\begin{aligned}
& C C A\left(€ / m^{2}\right)=\sum_{i=1}^{n} M_{i} \times \lambda_{i} \\
& L C A\left(P t / m^{2}\right)=\sum_{i=1}^{n} M_{i} \times \gamma_{i}
\end{aligned}
$$

Where $M_{i}$ is the ratio of material used per square meter, $\lambda_{i}$ is the unit cost of material and placement for each square meter (see Table 1), and $\gamma_{i}$ is the unit impact of material along with its production and subsequent placement per square meter measured in ecopoints (see Table 2).

The crux of this methodology lies in the difficulty of assigning a value to social impact. As noted in the introduction, social impact can be determined as a function of the total economic activity created in a particular region during the manufacturing of each functional unit.
Let us turn to the case study, which is located in Spain, where investments in residential construction represent the principal source of income, through direct taxation, to significantly contribute to the coffers of local administrations. These investments are also an inherent indirect source of wealth, growth and jobs. According to expert estimations (28), these investments generate an average of 2.43 jobs per household. Additionally, and among other positive economic factors, let us recall the social security contributions, income tax payments on worker salaries, corporate taxes, and also savings in unemployment and social security benefits.

The economic activity generated is divided and factored in as a percentage of the total solution cost. In this manner, some materials are nationally sourced, such as steel or cement; while others are regionally sourced, such as concrete or steel reinforcement. And lastly, material placement is designated as local. EPS is a special case in that the taxable portion of the raw material is exclusively international. The lone Spanish EPS manufacturer announced the cessation of its activities towards the end of 2013. Table 3 summarises these assumptions. Herein, each element involved in a structural solution has been assigned a fraction of the economic activity that corresponds to the distance between its manufacturing location and the construction site (d).

\begin{tabular}{|c|c|c|c|c|c|c|c|c|c|c|c|c|}
\hline Material & $\begin{array}{c}\mathrm{C} \\
(\mathbf{P t})\end{array}$ & $\begin{array}{l}\text { OR } \\
\text { (Pt) }\end{array}$ & $\begin{array}{c}\text { IR } \\
\text { (Pt) }\end{array}$ & $\begin{array}{c}\text { GWP } \\
\text { (Pt) }\end{array}$ & $\underset{(\mathbf{P t})}{\mathbf{R}}$ & $\begin{array}{c}\text { ODP } \\
\text { (Pt) }\end{array}$ & $\begin{array}{c}\text { ET } \\
\text { (Pt) }\end{array}$ & $\begin{array}{l}\text { Acid } \\
\text { /Eut } \\
\text { (Pt) }\end{array}$ & $\begin{array}{l}\mathbf{L U} \\
\text { (Pt) }\end{array}$ & $\underset{(\mathbf{P t})}{\mathbf{M}}$ & $\begin{array}{c}\text { Fuels } \\
\text { (Pt) }\end{array}$ & $\begin{array}{c}\text { Total gi } \\
\text { (Eco- } \\
\text { points) }\end{array}$ \\
\hline Steel columns (kg) & 0402 & 0,0001 & 0,0864 & 0,0110 & 0,0002 & 0,0000 & 0,0223 & 0,0053 & 0,0044 & ,0159 & 0,1093 & 0,2951 \\
\hline Steel beams and concrete & 0,0407 & 0,0001 & 0,0919 & 0,0128 & 0,0003 & 0,0000 & 0,0232 & 0,0062 & 0,0049 & 0,0164 & 0,1190 & 0,3153 \\
\hline Concrete pillars $\left(\mathrm{m}^{3}\right)$ & 0,0471 & 0,0021 & 1,5361 & 0,9598 & 0,0083 & 0,0002 & 0,1458 & 0,3028 & 0,1020 & 0,0437 & 2,8915 & 6,0394 \\
\hline Concrete beams and sl & 0,0471 & 0,0021 & 1,5361 & 0,9597 & 0,0083 & 0,0002 & 0,1458 & 0,3028 & 0,1020 & 0,0437 & 2,8915 & 6,0393 \\
\hline Hollow brick H2O (m) & 0,0221 & 0,0002 & 0,1949 & 0,0551 & 0,0007 & 0,0000 & 0,1166 & 0,0296 & 0,0310 & 0,0239 & 0,2694 & 0,7436 \\
\hline Hollow brick H25 (m) & 0,0262 & 0,0003 & 0,2314 & 0,0656 & 0,0009 & 0,0000 & 0,1385 & 0,0351 & 0,0367 & 0,0284 & 0,3199 & 0,8830 \\
\hline Hollow brick H3o (m) & 0,0309 & 0,0003 & 0,2728 & 0,0775 & 0,0010 & 0,0000 & 0,1633 & 0,0414 & 0,0432 & 0,0335 & 0,3771 & 1,0409 \\
\hline Hollow brick P2O (m) & 0,0012 & 0,0002 & 0,0682 & 0,0174 & 0,0000 & 0,0000 & 0,0024 & 0,0120 & 0,0005 & 0,0004 & 0,3392 & 0,4415 \\
\hline Hollow brick P25 (m) & 0,0015 & 0,0002 & 0,0842 & 0,0214 & 0,0000 & 0,0000 & 0,0030 & 0,0148 & 0,0006 & 0,0005 & 0,4185 & 0,5449 \\
\hline Hollow brick P3o (m) & 0,0018 & 0,0003 & 0,1011 & 0,0257 & 0,0000 & 0,0000 & 0,0036 & 0,0178 & 0,0008 & 0,0006 & 0,5023 & 0,6540 \\
\hline Reinforced joist (m) & 0,0521 & 0,0001 & 0,1346 & 0,0212 & 0,0004 & 0,0000 & 0,0449 & 0,0110 & 0,0104 & 0,0230 & 0,1740 & 0,4717 \\
\hline Prestressed reinforced joist (m) & o,0199 & 0,0001 & 0,0907 & 0,0200 & o,0003 & 0,0000 & 0,0442 & 0,0112 & 0,0139 & 0,0163 & 0,1213 & 0,3379 \\
\hline Column formwork $\left(\mathrm{m}^{2}\right)$ & 0,0439 & 0,0001 & 0,0985 & 0,0138 & 0,0003 & 0,0000 & 0,0221 & 0,0064 & 0,0055 & 0,0172 & 0,1733 & 0,3811 \\
\hline
\end{tabular}

Table 2. Ecoindicator'99 values for materials incorporated in the functional unit.

Carcinogenics (C), Respiratory organics (OR), Respiratory inorganics (IR), Global Warming (GWP), Radiation (R), Ozone Depletion (ODP), Eco-toxicity (ET), Acidification and Eutrophication (Acid / Eut), Land use (LU), Depletion of Minerals (M), Depletion of Fossils (Fuels).

Table 3. Allocation factors of economic activity - geographical location.

\begin{tabular}{|r|c|c|c|c|c|c|l|}
\hline Steel & Concrete & Lightening P & Lightening H & RCJ & PRCJ & $\begin{array}{c}\text { Column } \\
\text { formwork }\end{array}$ & \multicolumn{1}{|c|}{ Economic Activity } \\
\hline $0 \%$ & $0 \%$ & $50 \%$ & $0 \%$ & $0 \%$ & $0 \%$ & $0 \%$ & International $(\mathrm{d}>500 \mathrm{~km})$ \\
\hline $50 \%$ & $30 \%$ & $0 \%$ & $20 \%$ & $30 \%$ & $15 \%$ & $20 \%$ & National $(75 \mathrm{~km}<\mathrm{d}<500 \mathrm{~km})$ \\
\hline $30 \%$ & $40 \%$ & $40 \%$ & $55 \%$ & $35 \%$ & $45 \%$ & $0 \%$ & Regional $(25 \mathrm{~km}<\mathrm{d}<75 \mathrm{~km})$ \\
\hline $20 \%$ & $30 \%$ & $10 \%$ & $25 \%$ & $35 \%$ & $40 \%$ & $80 \%$ & Local $(\mathrm{d}<25 \mathrm{~km})$ \\
\hline
\end{tabular}


A main goal of the article is to summarise this considerable quantity of information to allow structure designers to make faster and more reliable decisions about forthcoming projects. Six key factors of the decision-making process, some of which we consider critical in the use of the methodology, were first identified: column index (CI), percentage of resistant section (\%RS), building components, environmental impact, economic impact and social impact. Incorporating those factors into our proposal ought to be mandatory. Three of the six parameters (CI, \%RS and building components) are related to project's initial stage.

CI: This index is used to define the layout of columns for the building and should be compatible with the architectural plan. In the case study, the value of CI ranges from 0.053 to 0.089 .

\%RS: This term defines the total area of the construction that corresponds to the concrete beams. Therefore, the CI along with the \%RS define the dimensions of the main structural elements.

Building components: These comprise the proposal for the structural secondary element and its different layouts with the corresponding encoding solution. The basic components to be defined are the thickness of the floor slab, the linear structural element and the lightening element.

Environmental impact: This factor is measured in Ecopoints'99 and is very useful to compare different alternatives proposed in one study. To this end, in our proposal, all environmental impact categories are fused into a single value which is directly adopted as the integrated environmental evaluation.

Economic impact: The construction materials taken in consideration for each evaluation use to be specific for each structural solution. This term represents the total economic cost incurred for the construction of each structural solution.

Social Impact: This factor comprises the percentage of productive activity that is theoretically created by each solution at the predefined geographical locations.

In brief, the proposed methodology, which is based on the six aforementioned parameters, compares and evaluates a series of structural solutions. The main challenge is the optimization of the design of the two structural components at the same time: the principal component composed of beams and columns, and the secondary one mainly composed of floor slabs. In residential construction, all the proposed solutions comprised one-way floor slabs. Finally, one of the most basic requirements for the structural solutions is that they have to be technically feasible and comply with current regulations.

The most interesting and quantitative information was obtained by locating each of the CI values on the Pareto fronts and then selecting the optimal Pareto values. In order to offer a novel perspective, the economic and social impact of each proposal was evaluated and incorporated into this methodology. Social impact offers the decision-making process additional information that, although it may interest engineers and architects concerned about the impact of their decisions, is extremely difficult to evaluate.

\section{RESULTS AND DISCUSSION}

In this section, the results of 360 alternatives are studied jointly, excluding those results which did not comply with the limits established by the current Spanish standards. Figure 3 summarises the results for the four proposed typologies

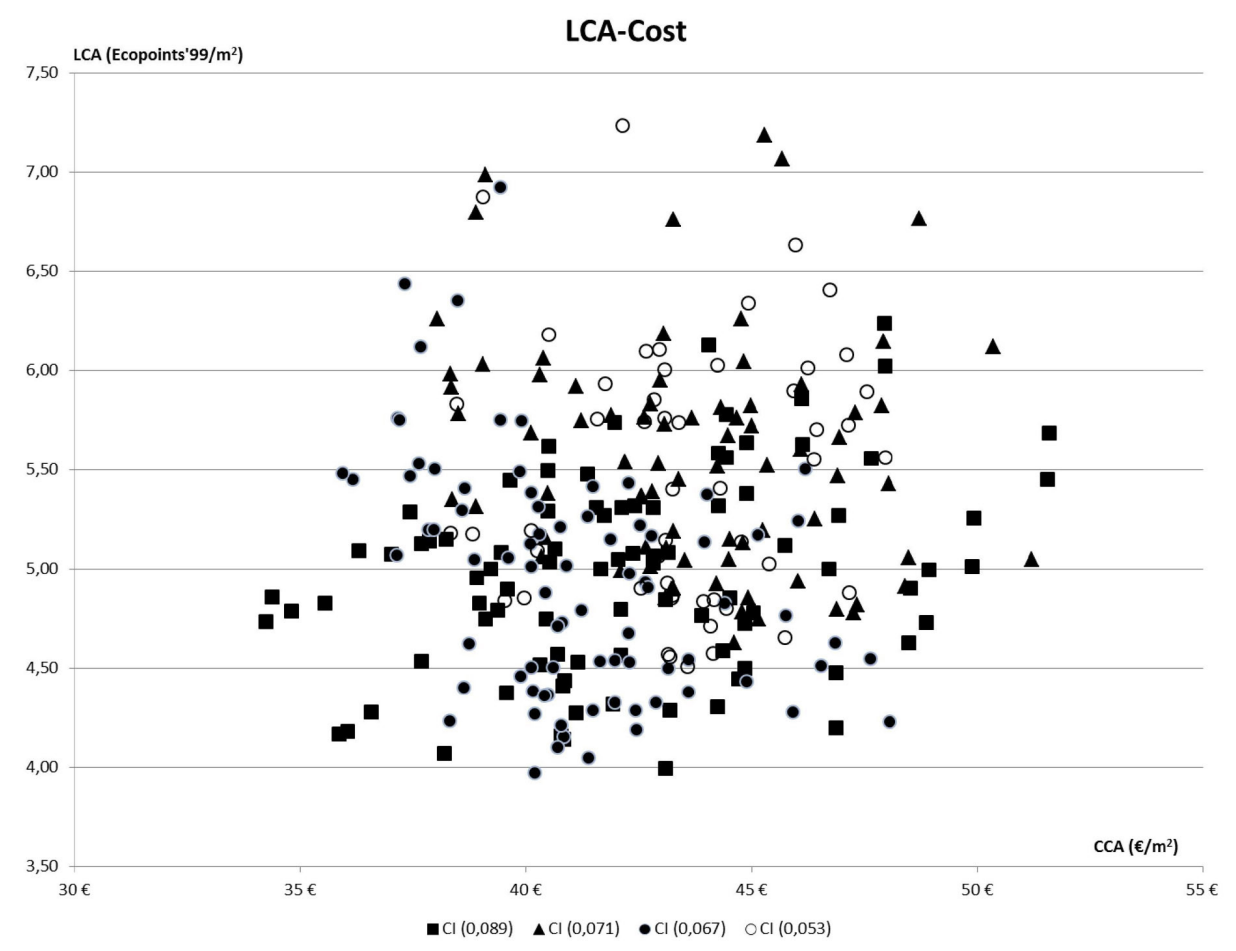

Figure 3. Results of all structural alternatives analysed using the methodology proposed. The back squared corresponds to solutions with $\mathrm{CI}=0.089$, black triangle is $\mathrm{CI}=0.071$, black circle is $\mathrm{CI}=0.089$ and empty circle corresponds to $\mathrm{CI}=0.053$. 
of column layout. When the environmental impact was not taken into consideration, the CI value of 0.089 is, without a doubt, the best structural solution from the perspective of economic cost. However, when the environmental impact is included in the evaluation, the best result is obtained with both $\mathrm{CI}=0.089$ and $\mathrm{CI}=0.067$.

The values of the economic impact, range from $€ 34.23$ to $€ 51.60$, which represents a percentage of $51 \%$. This could be considered a significant variation in cost per each square meter of structure. On the other hand, the environmental impact varies between 3.82 and 7.05 ecopoints, which corresponds to a total variation of $84 \%$. Then, the results are divided according to CI values, which represent the best solutions belonging to the Pareto front, and are summarised in Figure 4. The boundary values represent the best solutions, including both social and economic impact, for the building in question. Figure 4 and 5 display a combination of the three pillars of sustainable construction: economic, environmental and social. The optimal solutions with their different values for cost, environmental and social impact can be easily identified according to their CI values.

In this sense, the final results can be analysed in detail:

Solution CI $=\mathbf{0 . 0 5 3}$ : The optimal widths for the slab thickness are between 30 and $35 \mathrm{~cm}$ and the percentage of area allocated to the main structural element is from 16 to $20 \%$. This represents a more inexpensive local solution but, those solutions with a lower cost always entail a greater environmental impact. From an environmental point of view, the best alternative is achieved by using both PRCJ and EPS for the slab configuration; however, this is also the most expensive of them.

Solution CI $=\mathbf{0 . 0 6 7}$ : The optimal slab thicknesses are 25 and $30 \mathrm{~cm}$ and the percentage of area assigned to the main structural element is $10 \%$. The solutions with lower costs are

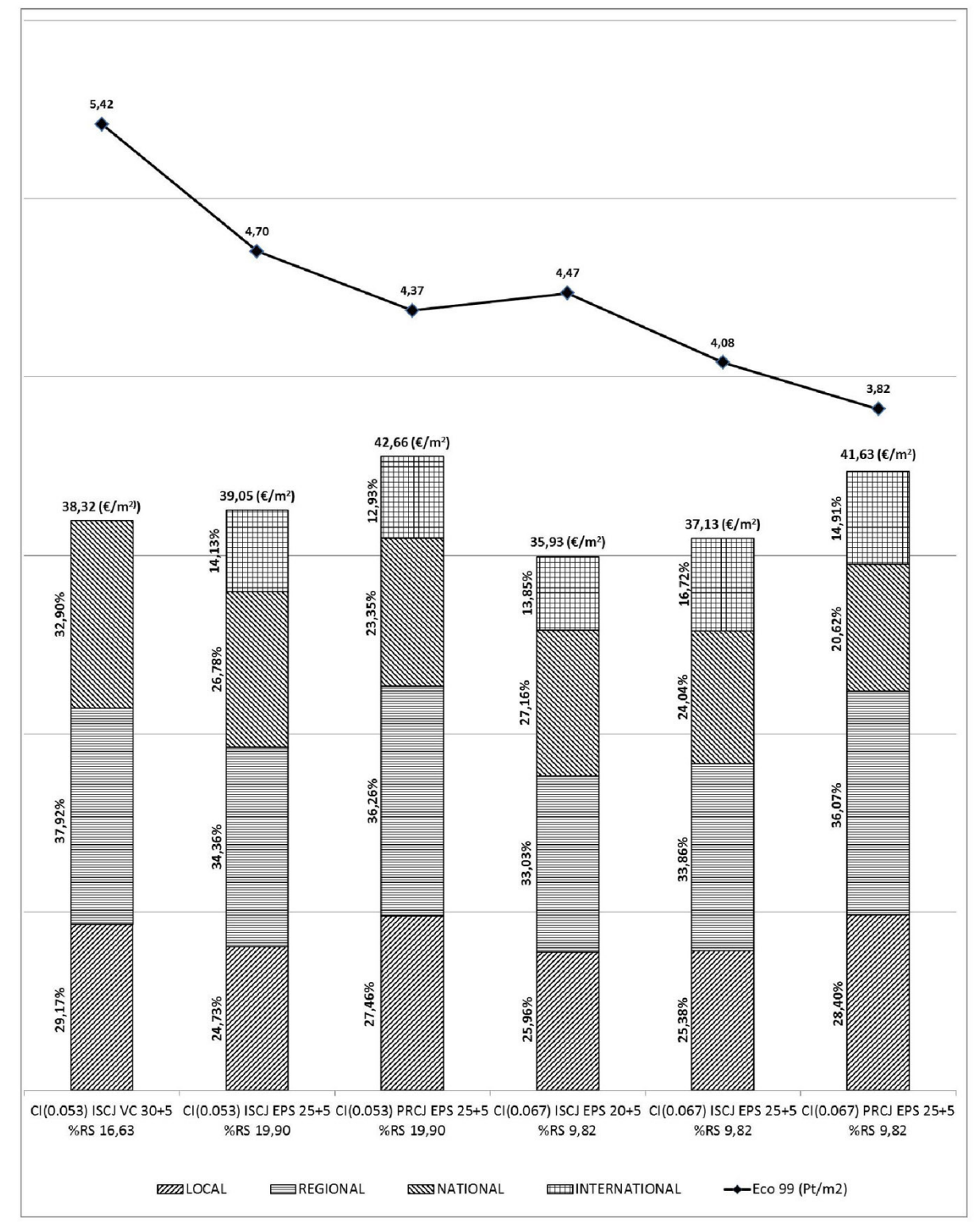

Figure 4. Evaluation of the Pareto-optimal structural solutions from $\mathrm{CI}=0.053$ to $\mathrm{CI}=0.067$. The barplots represent the total price per square meter and the percentage per predefined geographical locations (see Table 3). The solid line is the final Ecoindicator'99 value assigned to each solution. 


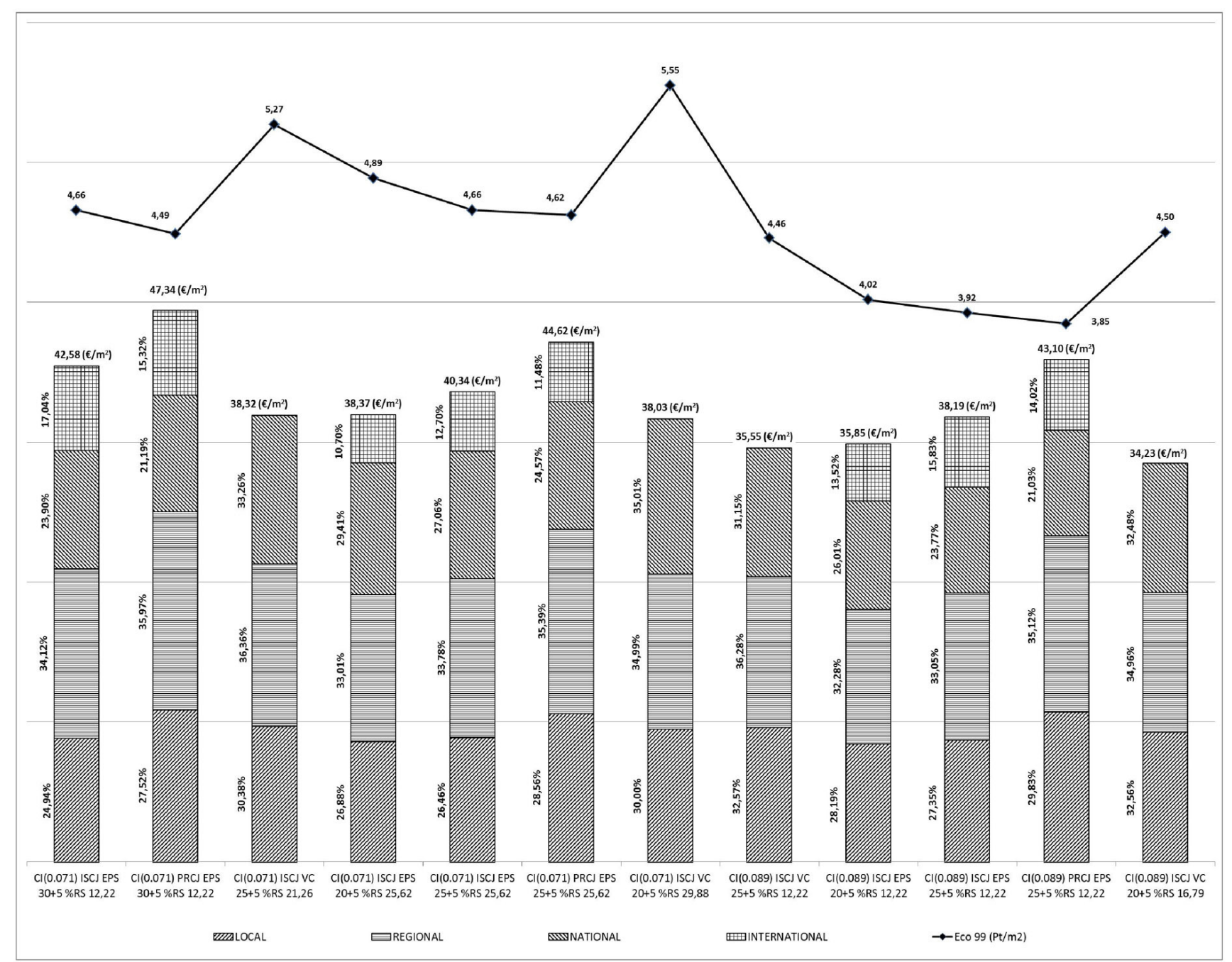

Figure 5. Evaluation of the Pareto-optimal structural solutions from $\mathrm{CI}=0.071$ to $\mathrm{CI}=0.089$. The barplots represent the total price per square meter and the percentage per predefined geographical locations (see Table 3). The solid line is the final Ecoindicator' 99 value assigned to each solution.

achieved using in situ slabs or EPS as lightening element; however, they also spur greater environmental impact. On the contrary, the best choice from the environmental standpoint is attained combining PRCJ, EPS as lightening element and a slab thickness of $30 \mathrm{~cm}$. This solution is also the most expensive solution on the Pareto front and the absolute minimum for this section. In this case, the increase of CI provides better performance than the preceding choice $(\mathrm{CI}=0.053)$.

Solution CI $=$ 0.071: The optimal slab thickness are 25, 30 and $35 \mathrm{~cm}$ and the percentage of area designated for the main structural element is between 12 and $30 \%$. The most economical solutions are also achieved using in situ slabs but, with a more significant environmental impact. Again, the best option from the environmental point of view continues to be a combination of PRCJ, EPS and a slab thickness of $35 \mathrm{~cm}$. This is the most expensive of the Pareto front solutions, while also representing the relative minimum for this section.

Solution CI $=$ o.o89: The optimal thickness have a width of 25 and $30 \mathrm{~cm}$ and the percentage of area allocated to the main structural element is between 12 and $17 \%$. In situ slabs achieve the most economical solutions but, again with a greater environmental impact. The best alternative from the environmental standpoint, and also the relative minimum, is the use of PRCJ and EPS.

Each proposal is introduced by identifying the location of the social impact incurred. In all the cases studied, the solutions with a markedly local nature entail lower economical costs, as well as an increased environmental impact. It should be noted that all the structural alternatives combining EPS as lightening material with prestressed joists consistently generated the optimal solutions with the lowest environmental impact; however, they were also the most expensive alternatives.

Obviously, the utilisation of different kinds of resources directly influences the impact generated by a given solution. Those alternatives that offer lower specific weights performed better in LCA:

In case of the lightening elements, the environmental impact of one kilogram of EPS is 32.6 times higher than VC. However, the density of the latter is 56 times greater than EPS. Taking into consideration these values, we concluded that 
structural solutions using EPS consistently produce solutions of a lower weight. Thus, the final decision seems to be clearly oriented toward the use of EPS.

In the case of linear structural elements, only prestressed reinforced and in situ joists seem to be optimal solutions. The former clearly provides a more efficient use of materials, while the latter generates a significantly lower impact during production.

It is important to note that the Pareto front solutions for lower CI never exceed the $20 \%$ on the parameter \%RS. The best LCA value corresponds to a $\% \mathrm{RS}$ of 12.22 for a $\mathrm{CI}=0.071$. The rest of the cases are over $20 \%$ with greater environmental impacts.

Concerning economical cost, the approaches using precast concrete and in situ structural elements shows clear differences. These differences are evident in the range of CI values. However, it is even greater for the case of $\mathrm{CI}=0.071$ with a minimum value of 38.03 euros per square meter for ISCJ $\mathrm{VC} 20+5$ with $\% \mathrm{RS}=29.88$, in contrast to the alternative PRCJ EPS $30+5$ with $\% \mathrm{RS}=12.22$, and a cost of 47.34 euros per square meter. In this case, the difference continues to be the environmental impact, which is $\mathbf{2 3 . 6 0} \%$ higher than the most inexpensive proposal, and the geographical location of the social impact.

Regarding the social impact on local and regional areas, limited variations and fluctuations occur between the extreme values of $7.84 \%$ and $5.64 \%$, respectively. Finally, these variations correspond to $14.39 \%$ and $17.04 \%$ for the national and international impact, respectively. This situation is mainly due to solutions requiring high proportions of steel in low slab thickness as well as the inclusion of EPS, which is the sole material with international impact. When local and regional impacts are considered together, the average value is $63.60 \%$, the minimum value decreases to $58.99 \%$ and finally, the maximum value is $68.65 \%$. These solutions are completely different because the minimum value is generated from ISCJ EPS $20+5 \%$ with $\mathrm{CI}=0.067$ and $\% \mathrm{RS}=9.82$, while the maximum comes from ISCJ VC $25+5$ with $\mathrm{CI}=0.089$ and $\% \mathrm{RS}=12.22$; however, their impact values (4.47 and $4.46 \mathrm{Pt} / \mathrm{m}^{2}$ ) as well as their prices (35.93 and 35.85 euros per square meter) are similar. The most significant difference between the two proposals is found in the possibility of adapting the architectural solution to a specific CI to obtain a greater impact in areas near the final project location.

\section{CONCLUSIONS}

This article presents a reliable methodology for selecting the optimal structural solutions for residential building by incorporating the three pillars of sustainable construction: economic, environmental and social. This proposal allows engineers and architects to evaluate different alternatives simultaneously on the basis of an architectural criterion, such as CI, combined with different options for the primary and secondary structural elements. A total of 360 possible solutions are initially selected for the particular case study. After an initial structural analysis to find the technically correct, the solutions are reduced to 301 (83.61\%). After application of the methodology the most interesting structural options are obtained, representing $5 \%$ of the initial cases. In authors' opinion, this can ease making the decision making process easier. The division range of CI parameter models, in a discrete and representative fashion, the numerous possibilities of column arrangements for residential building. Note that the most economical solutions for each slab thickness are generated using $\mathrm{CI}=0.089$. In the case of recently built structures however, the CI is closer to 0.053 than to 0.089 . This is due to the tedious process of combining both architectural design and column layout.

The simultaneous optimisation of the primary and secondary structures can only be achieved with an approach based on short beams and long slabs generating a CI $=0.067$. This CI also appears attractive for both its costs and environmental impact.

Incorporating metadata (such as CI) into the methodology sheds some light on the feasibility study of different columns arrangements without needing to calculate the whole structure. The results demonstrate the relevance and usefulness of the proposed methodology for sustainable construction. Specifically, social impact assessment must be incorporated into the decision-making process. Due to its prescriptive nature, this assessment takes on even more relevance during the initial phase of the project.

And finally, our methodology allows an objective and flexible assessment to be carried out during the design stage. Economic activity in the area where the structure is constructed clearly promotes increased social welfare. Greater environmental impacts accompanied by a more significant social impact may be permissible in certain circumstances of serious economic crisis.

\section{REFERENCES}

(1) Bernardos, G. (2009). Creación y destrucción de la burbuja inmobiliaria en España. Información Comercial Española ICE: Revista de economía, (850): 23-40.

(2) Instituto Nacional de Estadística. (2008-2013) Directorio Central de Empresas INEbase. http://www.ine.es.

(3) AENOR-CEN. (2014). UNE-EN 15804:2012+A1:2014. Sustainability of construction works - Environmental product declarations - Core rules for the product category of construction products. Asociación española de normalización (AENOR).

(4) Cellura, M., Guarino, F., Longo, S., Mistretta, M., Orioli, A. (2013). The role of the building sector for reducing energy consumption and greenhouse gases: An Italian case study. Renewable Energy, 60: 586-597, doi: http://dx.doi.org/10.1016/j. renene.2013.06.019.

(5) Sesana, M.M., Salvalai, G. (2013). Overview on life cycle methodologies and economic feasibility for nZEBs. Building and Environment, 67: 211-216, doi: http://dx.doi.org/ 10.1016/j.buildenv.2013.05.022.

(6) Rincón, L., Castell, A., Pérez, G., Solé, C., Boer, D., Cabeza, L. F. (2013). Evaluation of the environmental impact of experimental buildings with different constructive systems using Material Flow Analysis and Life Cycle Assessment. Applied Energy, 109: 544-552, doi: http://dx.doi.org/10.1016/j.apenergy.2013.02.038. 
(7) Bonham, M.B. (2012). Leading by example: new professionalism and the government client. Building Research \& Information, 41(1): 77-94, doi: http://dx.doi.org/10.1080/09613218.2013.743251.

(8) AENOR-CEN. (2012). UNE-EN 15978:2012. Sustainability of construction works - Assessment of environmental performance of buildings - Calculation method. Asociación española de normalización (AENOR).

(9) CEN/TC. (2014). EN 16309:2014. Sustainability of construction works - Assessment of social performance of buildings - Calculation methodology. Comité europeo de normalización (CEN).

(10) Zabalza, I., Valero, A., Aranda, A. (2011). Life cycle assessment of building materials: Comparative analysis of energy and environmental impacts and evaluation of the eco-efficiency improvement potential. Building and Environment, 46(5): 1133-1140, doi: http://dx.doi.org/10.1016/j.buildenv.2010.12.002.

(11) Aguado, A. (2006). Aplicación de índices de sostenibilidad medioambiental al proyecto de estructuras de hormigón. Nuevas tendencias del hormigón en el ámbito de una construcción sostenible. Madrid: CEDEX-ACHE.

(12) Burón-Maestro, M. (2007). La sostenibilidad de las construcciones de hormigón. Cemento Hormigón, (897): 58-65.

(13) Tenorio, J.A., Vega-Catalán, L., Turmo, J., Burón, M., Alarcón, A., Martín-Consuegra, F., Burón, A., D’Andrea, R.(2010). Los requisitos del Código Técnico de la Edificación. Eficiencia energética e incremento de la sostenibilidad. Aplicación a los edificios de hormigón. Cemento Hormigón, 937: 60-81.

(14) Kloepffer, W. (2008). Life cycle sustainability assessment of products. The International Journal of Life Cycle Assessment, 13(2): 89-95, doi: http://dx.doi.org/10.1065/lca2008.02.376.

(15) Huedo, P., López-Mesa, B. (2013). Review of tools to assist in the selection of sustainable building assemblies. Informes de la Construcción, 65(529): 77-88, doi: http://dx.doi.org/10.3989/ic.11.048.

(16) Jørgensen, A., Le Bocq, A., Nazarkina, L., Hauschild, M. (2008). Methodologies for social life cycle assessment. The International Journal of Life Cycle Assessment, 13(2): 96-103, doi: http://dx.doi.org/10.1065/lca2007.11.367.

(17) Hunkeler, D. (2006). Societal LCA Methodology and Case Study (12 pp). The International Journal of Life Cycle Assessment, 11(6): 371-382, doi: http://dx.doi.org/10.1065/lca2006.08.261.

(18) Norris, G. (2006). Social Impacts in Product Life Cycles - Towards Life Cycle Attribute Assessment. The International Journal of Life Cycle Assessment, 11(1): 97-104, doi: http://dx.doi.org/10.1065/lca2006.04.017.

(19) Fraile-García, E. (2012). Análisis multicriterio de forjados unidireccionales. In Mechanical Engineering. Logroño: University of La Rioja.

(20) Ferreiro-Cabello, J. (2013). Metodología de optimización para soluciones estructurales en edificación residencial. In Mechanical Engineering. Logroño: University of La Rioja.

(21) Pacios-Alvarez, A., Martos, G. (2008). Estimación del Îndice de Contribución de la Estructura a la Sostenibilidad en ejemplos de edificación. Cemento Hormigón, 913: 70-83.

(22) Tsai, W.H., Lin, S.J., Liu, J.Y., Lin, W.R., Lee, K.C.. (2011). Incorporating life cycle assessments into building project decision-making: An energy consumption and CO2 emission perspective. Energy, 36(5): 3022-3029, doi: http://dx.doi. org/10.1016/j.energy.2011.02.046.

(23) Reza, B., Sadiq, R., Hewage, K. (2011). Sustainability assessment of flooring systems in the city of Tehran: An AHP-based life cycle analysis. Construction and Building Materials, 25(4): 2053-2066, doi: http://dx.doi.org/10.1016/j.conbuildmat.2010.11.041.

(24) Pons, O., de La Fuente, A. (2013). Integrated sustainability assessment method applied to structural concrete columns. Construction and Building Materials, 49: 882-893, doi: http://dx.doi.org/10.1016/j.conbuildmat.2013.09.009.

(25) De Medeiros, G.F., Kripka, M. (2014). Optimization of reinforced concrete columns according to different environmental impact assessment parameters. Engineering Structures, 59: 185-194, doi: http://dx.doi.org/10.1016/j.engstruct.2013.10.045.

(26) ITec. (2013). BEDEC - Banco Estructurado de Datos de Elementos Constructivos. http://itec.es/nouarbrebedec.e/ menu2.aspx?tcq=o\&idbanc=0. Instituto de Tecnología de la Construcción de Cataluña (ITeC).

(27) Hischier, R., Weidema, B. (2009). Documentation of changes implemented in ecoinvent Data v2.1. Final report ecoinvent data v2.1.

(28) SEOPAN (2014). Asociación española de empresas constructoras de ámbito nacional Observatorio de la Construcción. http://www.seopan.es. 